\title{
Compliance Management in Bidding Procurement
}

\author{
Dan ZHANG ${ }^{1, a,{ }^{*}}$, Zhi-Dong LIANG $^{1, a}$, Jian-Hua GAO ${ }^{1, a}$
}

${ }^{1}$ CNPC Tublar Goods Research Institute, Xi'an, Shaanxi Jin Ye Road No. 89,710077

\begin{abstract}
Keywords: Bidding, Compliance, Institutional system, Monitoring mechanism.
\end{abstract}
\begin{abstract}
Compliance management is a core risk management activity within an enterprise. Purchasing is the economic behavior that ensures the normal operation and continuous development of enterprises. Bidding is the most common procurement method. This paper analyzes the risk points and non-compliance behaviors of all aspects of the bidding, and proposes ways to improve the compliance management in the bidding process, such as perfecting the system, building the supervision mechanism and improving the practitioners' practice level.
\end{abstract}

\section{The Importance of Compliance Management in Bidding}

In recent years, the term "compliance management" has been advocated and applied in the supervision and management of various fields in China. The work of enterprises in accordance with the management system to carry out the normal development of enterprises is the premise and guarantee. Compliance management is a core risk management activity within an organization. Enterprise compliance management has three meanings: First, compliance management is based on pr-compliance business risk management activities, both regulatory functions of regulatory activities in the enterprise extension, but also endogenous enterprise management requirements; Second, The compliance management of the enterprise shall be guided by the supervisory department and be in high consistency with the supervision target of the supervision department. Thirdly, the whole process of enterprise management shall include compliance management.

Procurement is the protection of the enterprises development and growth, and the bidding is the most common way of procurement. General enterprises will be based on the characteristics of the enterprise in the national bidding procurement laws and regulations on the basis of the development of enterprises for the procurement of management system, to guide enterprises bidding procurement compliance. As procurement is an economic behavior of enterprises, the whole process involves multiple interests, thus, procurement staff will face a variety of material temptations, so enterprises is very seriously to procurement of special audit. Bidding procurement has become a multi-concern behavior, but also an important object to promote compliance management.

\section{Risk in the Bidding Procurement}

Tenders include public tenders and invitational, according to the budget and nature of the project can choose the corresponding tender method. Public tenders is a society-oriented tender method, is the greatest degree of open and transparent procurement methods. In accordance with the principle of relative concentration, moderate competition and reasonable distribution of audience, the "Tender Notice Issuance Interim Measures" shall specify newspapers, networks and other media for the public announcement of the public tenders project, and to supervise the public announcement activities of the tenders.

\section{The Choice of Procurement Methods}

Enterprise procurement methods generally include bidding, inquiry, order, consultation, competitive bidding and single-source. Purchasers according to the budget and nature of the project can choose the corresponding tender method. Bidding is a kind of procurement method that relatively open and suppliers is ordered competition, the greater degree of competition, so that buyers can purchase the best cost-effective products. Other procurement methods are less open, access to information has been limited and limited participation in competitive suppliers, many excellent suppliers may be 
difficult to participate in procurement projects.

In many procurement projects, the purchaser intends to avoid tender. Avoid tender refers to the tender in various ways to achieve the purpose of evading tenders. Such as the need to tender the project is not tender, the project must be tender is break up the whole into part in order to avoid bidding.

"Bidding and Bidding Law" and "Construction Project Bidding Scope and Scale Standard" stipulates that the following circumstances must be tender. Including large-scale infrastructure, utility projects and all or part of the use of state-owned capital investment or state financing projects and use of international organizations or foreign government loans and assistance funds projects. The Government Procurement Law clearly stipulates the minimum amount that must be tender for goods, services and works. For large enterprises with the relevant laws and regulations to develop applicable to the enterprise's tender requirements, and in the procurement process strictly enforced, from the procurement of the first step to ensure procurement compliance.

\section{Bidding}

A complete process of bidding and tendering including bidding, bid, bid opening, bid evaluation, winning the bid and sign the contract. Tendering and bidding ACTS is a strictly regulate the activities of the program.

The tenderee shall prepare the bidding documents according to the requirements of the project and issue the tender notice, accept potential bidders for registration, and organize the scene reconnaissance, answering questions, bid opening, bid assessment work. During the bidding process, the preparation of the bidding documents is one of the most important tasks in the process of organizing the bidding process. The quality of the bidding documents will directly affect the quality of the bidding and even determine the success or failure of the bidding work. Tender requirements, the bidder qualification requirements, evaluation criteria, the main terms of the contract must be clear in the bidding documents. Therefore, bidding for the tender and bid activities are legal, scientific, can attain the goal of the tender, has a fundamental effect. At the same time, the level of practice of tendering staff directly affect the quality of the tender and the tender activities of the compliance.

Unqualified behaviors in the bidding process are the establishment of unreasonable bidders conditions to exclude potential bidders and the information asymmetry provides the unequal bidding information to the different bidders and scoring standard settings with obvious tendencies, etc.

Bid is the bidders in accordance with the requirements of the bidding documents to prepare the tender documents, and submit the tender documents before the deadline to respond to the tender activities. The tender documents should respond to all the substantive requirements of the bidding documents. Therefore, the quality of the tender documents determines whether the bidder can win the bid and the tenderee can obtain the expected bidding effect.

The bid opening and bid evaluation are the key links in bidding and bidding activities. The bid opening is the time and place determined by the tenderee in the bidding documents, open the tender documents and announce the important contents of the tender documents, guarantee the right of all bidders, and safeguard the legitimate rights and interests of all parties. Bid evaluation is to review the qualifications of bidders and in accordance with the bidding documents listed in the bid evaluation method to score the bidder, and to determine the successful bidder candidates. Winning bid to determine the successful bidder, and in accordance with the bidding documents and tender documents signed a written contract. Thus completing the entire tender procurement activities.

Bid opening, evaluation process in the process of non-compliance are the bid opening process is not in accordance with the provisions of the form and the opening record is not complete and the evaluation process of intervention in the judges score, with a tendency to induce the judges to raise or lower a rating of the bidders and

not timely signing the contract or the terms of the contract contrary to the tender documents and tender documents and other acts. 


\section{Compliance Management in Bidding Procurement}

\section{Perfect Management System}

A perfect management system is the prerequisite and basis for carrying out the bidding work. Scientific and effective enterprise management system is of great significance to standardize enterprise behavior, improve economic efficiency, realize business objectives and promote the healthy development of enterprises. Enterprises should proceed from strengthening internal management, develop various procurement management methods, strengthen the procurement process of compliance, improve the transparency of procurement work, and increase the procurement of the tender rate.

\section{Effective Monitoring Mechanism}

Effective supervision mechanism is a strong guarantee for the tender work. The supervision of the bidding activities includes the supervision of the parties, the administrative supervision, the judicial supervision and the social supervision, in which the parties supervise the most direct and effective. Bidding parties directly involved in the bidding process and the tender activities have a direct relationship of interest, the tenderer and the bidder can be more directly between the roles of mutual supervision, so as to ensure the tender work compliance.

Enterprises should set up a special supervision and inspection positions to monitor the implementation of laws and regulations on tendering activities and Procurement scope, procurement methods, procurement procedures. Procurement staff of professional quality and professional skills to carry out supervision and inspection. Emphasizing the role of internal audit, control and supervision of business management activities. Through the review, inspection, appraisal and analysis of the information of the bidding and purchasing project to find out the problems in the management of tenders, and put forward rectification opinions to urge rectification, to promote the tender procurement management.

\section{Improve the Practice of Bidding and Purchasing Practitioners}

The practicing level and ability of the tenderers are directly related to the quality of the tender. Enterprise self-bidding project by its procurement department to organize their own, procurement staff generally less. General Enterprises procurement a wide range and most of the procurement work by the internal procurement department to tender their own, procurement staff is difficult to have a variety of procurement project expertise, do not understand the procurement object, procurement market, purchase price, will greatly reduce the quality of tender procurement.

Enterprises on the larger amount of the project will choose to entrust the tender agent for tender. The tender industry practitioners lower threshold, the ability of the tender agent company uneven. Enterprises choose the tender agent should select qualified and strong, good reputation, rich performance of the tender agency, the tender staff experienced, contact with the procurement of various types of relatively professional, high level of practice.

Whether it is self-tender or commissioned by the bidding enterprises should improve the practitioners according to the ability to act according to law, anti-corruption and anti-corrosion capacity, coordination and other aspects of the ability to improve the level of tenure and professionalism. So that enterprises bidding procurement work of high quality, high efficiency, legal compliance to carry out.

\section{References}

[1] Juan XIN. On Enterprise Compliance Management [J]. Enterprise Economy, 2010(4): 37-39

[2] Dan ZHANG, Zhi-Dong LIANG, Jian-Hhua GAO. Analysis of their own tender. Economist, 2016(3): 272-280

[3] Jing-Ying HUI, Ying REN, Feng-Jie LONG. Research on Project Bidding Management Risk. Experimental Technology and Management, 2014(10): 264-268 